\title{
Akuntabilitas Pengelolaan Keuangan Sekretariat Partai Demokrasi Perjuangan Gianyar Dan Klukung Provinsi Bali
}

\author{
${ }^{1}$ Ni Wayan Supriliyani , ${ }^{2}$ Ni Putun Prabhawati \\ ${ }^{12}$ Program Studi Ilmu Administrasi Negara Universitas Udayana \\ e-mail : ${ }^{1}$ supriliyani@unud.ac.id
}

\begin{abstract}
Abstrak
Transparansi dalam strategi pengelolaan keuangan Partai, masih menjadi persoalan atas pendanaan partai politik. Prinsip Akuntabilitas dapat memastikan tanggung jawab partai politik dalam proses menerima dan membelanjakannya sesuai etika. Administrasi publik berpotensi memberikan Sumber daya manusia yang memungkinkan Demokrasi, dan Transparansi dalam pengelolaan keuangan Partai. Sehingga mendorong terwujudnya tujuan Reformasi, Pembangunan yang Demokratis dan berkembang baik. Dalam pengaturan Undang-Undang No.2 Tahun 2008 partai politik wajib melaporkan keuangannya setiap tahun dan dilakukan di setiap tingkatan hingga Kabupaten/Kota. Metode Penelitian yang dilakukan adalah Metode Penelitian Kualitatif Deskriptif dengan memakai Proposif sampling. dalam pembahasan penelitian ini ditemukan pada proses pendanaan partai itu didapat dari iuran anggota Dewan, Bupati, dan wakil Bupati yang menjabat dari perwakilan partai PDIP menyatakan iuran yang didapatkan sangat sedikit, dan dana parpol yang spontanitas itu memang tidak ada perencanaannya dari awal. Dan berupa bantuan dana dari pemerintah yang jumlahnya cukup besar, sehingga dalam pelaksanaan strategi pengelolaan keuangan dari pemerintah masih mencari tenaga ahli untuk penyerapan anggaran partai PDIP Gianyar dan PDIP Klungkung. Di dalam segala proses keuangan administrasi sekretariat masih menggunakan secara manual belum dapat menggunakan Sistem Informasi Manajemen seperti apa yang diarahkan pemerintah sekarang.
\end{abstract}

Kata Kunci : Akuntabilitas, Kinerja, Pengelolaan Keuangan

\begin{abstract}
Transparency in the party's financial management strategy is still a problem with political party funding. The principle of accountability can ensure the responsibility of political parties in the process of receiving and spending them ethically. Public administration has the potential to provide the human resources that enable democracy, and transparency in the management of Party finances. So as to encourage the realization of the goals of Reform, Democratic Development and well-developed. In the regulation of Law No.2 of 2008, political parties are required to report their finances annually and this is done at every level up to the Regency / City. The research method used is descriptive qualitative research method using proposive sampling. In the discussion of this research, it was found that the party funding process was obtained from the contributions of members of the Council, Regent and Deputy Regent who served from representatives of the PDIP party stated that the contributions obtained were very small, and the spontaneous political party funds were not planned from the start. And in the form of financial assistance from the government which is quite large in number, so that in implementing financial management strategies the government is still looking for experts to absorb the budget of the PDIP Gianyar and PDIP Klungkung parties. In all secretariat administrative financial processes still use manually, the Management Information System as directed by the current government cannot be used.
\end{abstract}

Keywords: Accountability, Performance, Financial Management 


\section{PENDAHULUAN}

Partai Politik sekarang ini memang diminta dapat dilaksanakan secara Demokratis, sehingga pemahaman dalam strategi kinerja Partai Politik harus membangun kerjasama tim agar tercapainya nilai dan tujuan yang sama. Akuntabilitas Kinerja perwujudan dari pertanggung jawaban dalam mencapai misi dan tujuan Partai Politik dalam pelaksanaan konsep Governance yang di sampaikan melalui media maupun secara online yang berlaku pada peraturan Presiden (Perpres) Nomor 95 Tahun 2018 Tentang Sistem Pemerintahan Berbasis Elektronik (SPBE). Sehingga di bawah Peraturan Presiden yang tepat dengan pelaksanaan (INPRES) Nomor 7 Tahun 1999 mengeluarkan peraturan tentang Akuntabilitas Kinerja Instansi Pemerintahan sehingga tercipta suatu tata Pemerintahan yang Baik (Good Governance).

Sistem Akuntabilitas Kinerja pada Partai Politik di mulai dari rancangan perencanaan suatu manajemen kinerja, sehingga di tetapkan pengukuran kinerja, setelah berproses dalam pengumpulan data dan akhir pelaksanaan adalah pelaporan kinerja dalam suatu Partai Politik, dalam mewujudkan pertanggung jawaban yang transparansi demi Keadilan Sosial yang berlandaskan Good Governance. Suatu Organisasi Partai memang sangat membutuhkan sumber daya yang sangat handal dikarenakan harus dapat bekerja secara professional dalam pengelolaan keuangan. Sehingga Sumber Daya Manusia Parpol dapat mengikuti berbagai macam pelatihan dan pendidikan yang bertepatan dengan profesi dari masing-masing keahliannya.

Pada artikel JawaPos.com (2018) menerangkan bahwa telah terjadi kasus 2 orang tersangka atas kasus dugaan korupsi hibah dimana anggaran tersebut diperuntukan untuk pura akan tetapi tidak diberikan untuk anggaran pura sepeserpun. maka sebagai sasaran utama dalam pelaksanaan di setiap organisasi adanya mekanisme pegawai dengan melakukan system audit internal sebelum terjadi permasalahan yang akan membawa nama baik organisasi.

Sesuai peraturan kelembagaan Partai Politik yaitu tentang Peraturan Pemerintah Republik Indonesia Nomor 1 Tahun 2018 tentang "Perubahan Kedua Atas Peraturan Pemerintah Nomor 5 Tahun 2009 Tentang Bantuan Keuangan Kepada Partai Politik" menerangkan kelembagaaan Partai Politik melalui peningkatan bantuan keuangan kepada Partai Politik serta transparansi dan akuntabilitas pengelolaan bantuan keuangan partai politikberdasarkan permasalahan maka peneliti melakukan penelitian tentang Akuntabilitas Pengelolaan Keuangan Sekretariat Partai Demokrasi Perjuangan Gianyar Dan Klukung Provinsi Bali.

\section{METODE}

Dalam ini merupakan penelitian deskriptif dengan metode kualitatif, penelitian deskriptif dimaksudkan untuk pengukuran yang cermat terhadap fenomena social tertentu (Singa rimbun dan Effendi 1989:4). Penelitian ini menggunakan metode kualitatif.Metode kualitatif mengikuti prosedur penelitian yang menghasilkan data deskriptif, yaitu berupa kata-kata tertulis dari perilaku yang diamati (Moleong ,2005:16). Penelitian ini diarahkan pada penggambaran latar serta individu secara holistic (menyeluruh).Untuk memperoleh data secara holistik, maka teknik pengumpulan data dari penelitian ini adalah :

a) Observasi, yaitu teknik penelitian dengan melakukan pengamatan langsung kelokasi penelitian serta mencatat dengan sistematis fenomena yang diamati. Penggunaan teknik observasi ini dimaksudkan untuk mendapatkan data primer mengenai upaya yang dilakukan oleh badan teknis daerah terkait penyelenggaraan governance di pemerintah daerah. 
b) Wawancara adalah teknik pengumpulan data melalui Tanya jawab secara langsung dimana pihak penanya (interviewer) berhadapan langsung secara fisik dengan pihak yang ditanyai (interviewee). Metode wawancara yang digunakan pada penelitian ini adalah metode wawancara mendalam (in-depth interview) dengan berpedoman pada daftar wawancara yang sudah dibuat/ dipersiapkan sebelumnya (interview guide). Wawancara mendalam pada suatu penelitian bertujuan menghimpun keterangan tentang fenomena dalam masyarakat (Melly, 1994:129).

c) Studi dokumen yaitu kegiatan melakukan analisis terhadap dokumen- dokumen atau data tertulis yang berhubungan dengan penelitian dalam hal ini.

\section{Lokasi, Obyek dan Unit Analisis}

Penelitian ini dilakukan diSekretaria PDIP Gianyar dan PDIP Klungkung yang akan dilakukan berdasarkan purposive sample.

Unit Analisis penelitian berada pada tingkat institusi dan individu,yaitu Sumber Daya Manusia di lingkungan kantor PDIP Gianyar dan Kantor PDIP Klungkung.

Tabel 1. Informan Penelitian

\begin{tabular}{clc}
\hline Informan & \multicolumn{1}{c}{ Alasan } & Teknik pengumpulan data \\
\hline Sumber daya manusia & Sebagai salah satu pihak yang & Wawancara (depth interview) \\
& memiliki kewenangan dan & \\
& tanggung jawab dalam laporan & \\
& akuntabilitas keuangan parpol & \\
& PDIP
\end{tabular}

$\begin{array}{lll}\text { Kepala sekretariat PDIP } & \begin{array}{l}\text { Sebagai pihak pelaksana } \\ \text { kebijakan di sekretariat PDIP }\end{array} & \text { Wawancara dan data sekunder }\end{array}$

\begin{tabular}{lll}
\hline DPRD bagian anggaran & $\begin{array}{l}\text { Sebagai pihak pelaksana } \\
\text { kebijakan }\end{array}$ & Wawancara dan data sekunder
\end{tabular}
kebijakan

\section{Teknik Pengumpulan Data}

Penelitian ini dilakukan dengan mengumpulkan data-data primer dan data sekunder. Data Primer yaitu data yang diperoleh dari observasi langsung kelokasi penelitian dan hasil wawancara terhadap instansi terkait, khususnya kepala Sekretariat PDIP Gianyar dan Klungkung. Data primer, dilakukan melalui dua cara yakni, Pertama; melalui observasi dimana penulis terjun langsung dan berinteraksi dengan obyek penelitian untuk mendapatkan informasi yang seobyektif mungkin. Kedua, wawancara langsung, yaitu dengan Tanya jawab langsung dengan pihak-pihak atau unsur-unsur dari obyek terkait, dan unsur-unsur tersebut dimintai keterangan sesuai dengan masalah yang dibahas. Wawancara dilakukan secara semi struktur, wawancara in tergolong dalam in-depth interview. Tujuan dari wawancara ini adalah untuk menemukan permasalah lebih terbuka dimana pihak yang diajak wawancara diminta pendapat dan ide-idenya (Sugiyono, 2010:320). Data sekunder diperoleh dari dokumen, pengumpulan literature, kerya tulis serta peraturan perundang-undangan yang berubungan dengan permasalahan yang ada serta sifatnya mendukung data 


\section{Teknik Analisis Data}

Analisis dalam penelitian adalah dengan interprestasi terhadap data, fakta dan informasi yang telah dikumpulkan melalui pemahan intelektual yang dibangun atas dasar pengalaman empiris dengan langkah-langkah: 1)Pengumpulan data; 2) Penilaian data; 3) Interprestasi data; 4) Penyimpulan data terhadap hasil interprestasi data dan analisis data

\section{HASIL DAN PEMBAHASAN}

Akuntablitas kinerja dalam strategi pengelolaan keuangan partai politik pada secretariat PDI Perjuangan Gianyar dan Sekretariat PDI Perjuangan Klungkung mampu menjawab beberapa pertanyaan yang ditanyakan oleh peneliti, baik meliputi sumber-sumber keuangan partai, proses melakukan perencanaan anggaran, penggunaan system berbasis elektronik yang berdasarkan peraturan presiden No. 95 tahun 2018, serta partisipasi anggota dalam penentuan anggaran. Melalui proses wawancara dengan bapak kepala sekretariat.

Pengaturan keuangan partai politik bukan melarang partai politik menerima sumbangan dari pihak luar, melainkan mengatur sedemikian rupa sehingga partai politik masih memiliki keleluasaan mengumpulkan dana untuk membiayai kegiatan partai, tapi tetap terjaga kemandiriannya dalam memperjuangkan kepentingan rakyat. Berdasarkan hasil penelitian bahwa sumber dana partai PDIP Gianyar diperoleh dari iuran dari masing-masing anggota yang meliputi anggota fraksi yang berkedudukan sebagai anggota dewan maupun kader yang berkedudukan sebagai bupati maupun wakil bupati. Dimana para anggota itu wajib menyetorkan iuran kepada partai yang berdasarkan SK DPP yaitu sebesar $20 \%$ dari penerimaannya. Sumber kedua berasal dari bantuan keuangan pemerintah setiap tahunnya. Dan yang ketiga berasal dari dana tidak mengikat dari kader maupun simpatisan jika terdapat kegiatan-kegiatan seperti HUT dan lain sebagainya.

Dalam hal pengaturan pendapatan dan belanja kampanye yang berlangsung saat pemilu. Kampanye dalam kaitan ini dapat dilihat sebagai aktivitas pengumpulan massa, parade, orasi politik, pemasangan atribut dan pengiklanan partai. Dalam kampanye ini terdapat dana kampanye yang harus dilaporkan kepada KPU, alam penyusunan sudah sesuai dengan standar yang berlaku, dikarenakan memakai jasa akuntan public kalau untuk melapor ke KPU, tapi kalau untuk dipartai sendiri dibimbing lansung dari kesbanglinmas, mereka memiliki system, sedangkan partai berada dibawah kesbanglinmas.

Dari segi perencanaan antara pengeluaran dan pemasukan balance, hal ini dikarenakan dana yang dianggarkan tersebut sebelumnya sudah dirancang. Pada Permendagri No.36 Tahun 2018 tentang tata cara perhitungan, penganggaran dalam anggaran pendapatan dan belanja daerah, dan tertib adiministrasi pengajuan, penyaluran dan laporan pertanggungjawaban penggunaan bantuan keuangan partai politik sudah terdapat persentase untuk pembagian $\mathrm{RAB}$, dimana untuk pendidikan politik itu minimal $50 \%$ plus, sehingga yang $40 \%$ sisanya itu bisa dipakai untuk ATK, rapat-rapat, dan konsumsi.

Selain itu dalam hal penyusunan Rancangan Anggaran Biaya (RAB) narasumber menjelaskan bahwa hal tersebut sudah diatur dalam Permendagri No.36 Tahun 2018 tentang tata cara perhitungan, penganggaran dalam anggaran pendapatan dan belanja daerah, dan tertib adiministrasi pengajuan, penyaluran dan laporan pertanggungjawaban penggunaan bantuan keuangan partai politik.

"Hal tersebut sudah diatur dalam Permendagri, untuk pendidikan politik itu minimal 50+. Aggaran itu dipakai untuk pendidikan politik prioritas, kalau dulu ada acuannya 60\% kalau sekarang $50+$. Sehingga 40\% sisanya itu bisa dipakai untuk ATK, rapat-rapat, dan konsumsi."

Dalam Pelaksanaan Sistem Informasi Manajemennya pun kami sebagai peneliti sangat berkesima setelah wawancara karena masih menggunakan sistem secara manual, masih menunggu dari induk partai, dan takutnya nanti tidak nyambung antara DPC PDI yang satu dengan cabang yang lainnya, jika memang 
instruksi dari atas pasti akan diusahakan, kemungkinan sekarang setelah kongres karena PDI Perjuangan menjadi partai pelopor dan partai modern. sehingga sistem informasi mengenai keuangan disini masih belum sepenuhnya modern, seperti jaman sekarang yang sudah bijak menggunakan sistem online secara sempurna.

Pencapaian sasaran pada suatu program itu sudah mencapai $100 \%$ per tahunnya sudah mencapai kelayakan operasional tapi kalau target-target kursi suara itu baru bervariasi tidak bisa ditentukan.Dalam penggunaan sistem informasi manajemen pada partai PDIP masih bersifat manual dan masih sebatas penggunaan email. Hal ini dikarenakan sekretariat PDIP masih menunggu keputusan dari induk partai yang berada di pusat. Jikalau nantinya sekretariat PDIP membuat system ditakutkan tidak selaras dengan intruksi dari pusat. Jika nantinya terdapat intruksi dari pusat, secretariat PDIP juga akan mengusahakan terdapatnya system tersebut.

\section{KESIMPULAN}

Akuntabilitas Kinerja Dalam Strategi Pengelolaan Keuangan Partai Politik Sekretariat PDIP Gianyar dan Sekretariat PDIP Klungkung meliputi sumber-sumber keuangan partai yang berasal dari iuran dari masing-masing anggota baik yang menjadi anggota DPRD maupun Bupati/Wakil Bupati, sumber dana yang kedua berasal dari bantuan keuangan pemerintah setiap tahunnya serta yang terakhir dari dana tidak mengikat dari kader.Proses melakukan perencanaan anggaran dimana dalam perencanaan antara pengeluaran dan pemasukan balance, hal ini dikarenakan dana yang dianggarkan tersebut sebelumnya sudah dirancang. Dalam hal penggunaan system berbasis elektronik pada Sekretariat PDIP Gianyar dan PDIP Klungkung masih menggunakan sistem secara manual, hal ini dikarenakan dari induk partai sendiri belum mengeluarkan sistem yang berbasis elektronik sehingga pada secretariat belum menggunakan sistem yang berbasis online karena jika secretariat Partai PDIP yang membuat sistem online ditakutkan tidak selaras dengan cabang-cabang yang lainnya. Dan jika sudah diintruksikan dari atas pasti akan diusahakan.

\section{DAFTAR PUSTAKA}

[1] Nazrina Zuryani, 2014 Buku Ajar Akuntabilitas Partai Politik,Udayana University Press.

[2] Dunn,William.(2003).Pengantar Analisis Kebijakan Publik.Yogyakarta.GadjahMada UniversityPress.

[3] Fiona,F (2006)Critical Succes Factors for Enterprise Resource Planning Implementation and Upgrade, Journal of Computer Information Systems, University of Nebraska68588 - 0491.

[4] Halim, Abdul(2004) Manajemen Keuangan Daerah. Yogyakarta: (UPP) AMP YKPN.

[5] Moleong,LexyJ. 2000. Metodologi Penelitian Kualitatif, Bandung: PT. Remaja RosdaKarya.

[6] Nugroho, Riant,Dr. (2002) PublicPolicy. Jakarta: PT Elex Media Komputindo. Pramusinto, Agus, Dr.Prof.Seri Kebijakan Publik Indonesia dalam Demokrasi \& Good Governance. Yogyakarta : Institute of Governance and Public Affairs(IGPA). 
[7] Singarimbun, M dan Effendi, S. 1989.Metode Penelitian Survai. Jakarta:LP3ES Sugiyono, Dr,2010,n Metode penelitian KuantitatifKualitatif dan R\&D.Bandung: Alfabeta.

[8] Winarno,Budi.(2004)TeoridanKebijakanPublik.Yogyakarta:MediaPressindo

[9] JawaPos.com. 2018. Eks Sekretaris PDIP Klungkung TSK Korupsi Hibah, 1 TSK Lagi Ternyata. Tersedia di https://radarbali.jawapos.com/read/2018/12/18/109118/eks-sekretaris-pdip-klungkungtsk-korupsi-hibah-1-tsk-lagi-ternyata . 